\title{
A Theory of Entrepreneurial Work
}

\author{
Ying Lowrey, Danxia Xie \\ Institute of Economics, School of Social Sciences, Tsinghua University, Beijing, China \\ Email: ying-lowrey@tsinghua.edu.cn, xiedanxia@tsinghua.edu.cn
}

How to cite this paper: Lowrey, Y. and Xie, D.X. (2019) A Theory of Entrepreneurial Work. Theoretical Economics Letters, 9, 1507-1517. https://doi.org/10.4236/tel.2019.95097

Received: March 18, 2019

Accepted: June 17, 2019

Published: June 20, 2019

Copyright $\odot 2019$ by author(s) and Scientific Research Publishing Inc. This work is licensed under the Creative Commons Attribution International License (CC BY 4.0).

http://creativecommons.org/licenses/by/4.0/

\section{c) (i) Open Access}

\begin{abstract}
This research is inspired by Baumol's lifetime effort in introducing the entrepreneur to mainstream economics. The paper examines entrepreneurial work and suggests a return to classical economic theory of the entrepreneur in the tradition of Max Weber and Joseph Schumpeter. We assume entrepreneurial work to be the intrinsic character of the entrepreneur, who divides her working time into subsistence and entrepreneurial productions. The entrepreneur taking pleasure from entrepreneurial work is the crucial conjecture of our analytical model. The model predicts 1) maximum utility can be reached if and only if the market value of the marginal product of labor in subsistence production is greater than that in entrepreneurial production; 2) government interventions artificially alternating the price of subsistent production may lead to misallocation of limited labor time into the two productions.
\end{abstract}

\section{Keywords}

Entrepreneur, Work Ethic, Labor, Entrepreneurial Work

\section{Introduction}

The entrepreneur was first discovered, and then research on entrepreneurship was developed by people in the science of economics. There have been numerous papers and books that follow a functional approach-the entrepreneur is perceived as a business manager or an innovator who plays an important role in technological progress and economic growth ${ }^{1}$. And yet, as described by Filion [2], "It is never easy to introduce elements of rationality into the complex behavior of entrepreneurs. One of the criticisms that can be leveled at the economists is that they have not been able to make economic science evolve. They have also been unable to create a science of economic behavior of entrepreneurs". Although this seems to be an overstatement, as there has been a strong tradition of ${ }^{1}$ Among numerous studies, Baumol [1] is an outstanding example. 
behavioral study on entrepreneurs ${ }^{2}$, it is time to call for more rigorous research on entrepreneurial behavior.

The key flaw in the study of entrepreneurial behavior apparently is the lack of a "superstring" theory of the entrepreneur in economics3. Economists today seem to have lost their scientific curiosity as shown by many classical economists such as Max Weber and Joseph Schumpeter. What is entrepreneurship? How to define the entrepreneur? Such questions "are never laid to rest, perhaps social scientists relish semantic jousting or because a sense of what scientific inquiry requires drives them to keep hunting for the perfect fit between the definition of a phenomenon and the phenomenon itself".

In attempting to fill the gap between the definition of the entrepreneur and the entrepreneur itself, this paper suggests taking the entrepreneur's work ethic as the intrinsic character of entrepreneurs. Inspired by McClelland [4] and Maslow [5] [6], we name this work ethic as "entrepreneurial work". We do not merely realize the hardship in starting and growing businesses. Rather, we are more interested in the behavior of economic men who proactively utilize their profoundly basic human capital-their own labor that is embodied by 1) innate human capital such as body mass, IQ and EQ; 2) trained human capital such as education and other special training; and 3) accumulated experiences and skills to be an "innovative entrepreneur", as defined by Schumpeter-to do new things, or existing things in new ways, and to make things happen and get things done [7] [8]. Because entrepreneurs are engaged in creative activities fueled by their own passions and desires, entrepreneurs don't derive negative utility from their works; instead, they take pleasure in making such efforts.

The intension of this paper is to draw economists' attention to the starting point of entrepreneurial research in the science of economics, and in the tradition of Max Weber and Joseph Schumpeter. Our contribution through this paper to the research field is to construct an economic model of entrepreneurial work ${ }^{5}$. In a simple representative entrepreneur's utility maximization setting, we assume that the entrepreneur obtains a positive value from her entrepreneurial work in maximizing her utility, subject to budget constraints. The assumption about entrepreneurs deriving happiness from entrepreneurial work is not just a conjecture but also based on numerous evidences and surveys. For example, Clark and Tomlinson [9] reports an empirical research from a sample of the ${ }^{2}$ For instance, in 1982 Encyclopedia of Entrepreneurship, produced by Prentice-Hall, Inc., there were two chapters discussion of social aspects of entrepreneurship and one chapter of the psychology of the entrepreneur.

${ }^{3}$ In the field of natural science, physicists, such as Albert Einstein, attempt to use the so-called unified field theory to explain everything from a dropping apple to the movement of quarks. Some physicists believe that everything in the world consists of a tiny, one-dimensional loop, each particle contains a vibrating, oscillating, and dancing filament called a string. Some physicists proclaim that Superstring Theory, a Theory of Everything (TOE), may unify the forces of nature. ${ }^{4}$ p. 92, Kent A. Calvin, Donald L. Sexton and Karl H. Vesper [3].

${ }^{5} \mathrm{We}$ intend to adapt a positive rather than a normative approach for this paper. Therefore, we omit issues such as entrepreneurial effort might lead to be productive, unproductive or destructive in the economy. 
1992 Employment in Britain Survey. The authors find that effort levels are increasing in wages as well as in preferences for work over leisure. Those were likely to report that they provided a greater amount of effort than required were those who agreed the most with the survey statement that "hard work is fulfilling in itself”. The US Census' Current Population Survey (CPS) accumulates a good database that can also be explored to illustrate the situation of US entrepreneurial work as well as the impacts of such work on the US economy ${ }^{6}$.

The structure of the paper is as follows. Section 2 sets up the model and analyzes the equilibrium. Section 3 extends the basic model by introducing government intervention. Section 4 concludes the paper.

\section{The Model}

In this section, we construct a theoretical model for the entrepreneurial economy, with two types of labor and two types of productions. We model the entrepreneur as a representative agent. She has all the characteristics of a consumer as well as of a producer. The entrepreneur has to decide how to divide her labor effort into these two types of productions. However, the entrepreneur's subjective views of the utility or disutility derived from devoting efforts to these activities differ. To better understand the distinctions in those two different productions and two different utility functions from exerting effort in producing the two products, the authors review model related literature in the following subsection.

\subsection{Background}

Schumpeter [11] deeply examined two different labor efforts. Considering human needs for life, he noticed that people were unwilling to work on daily routine. "Thousands of voices from everyday life remind us that the work concerning our daily bread is a heavy burden, which one only undergoes because one must, and which one throws off if one can"7. For ordinary people, making such effort for survival would be difficult. They would be unwilling to do something new than what is familiar and tested by experience and would be reluctant "even if the objective difficulties did not exist". However, this situation would not apply to a "new and another kind of effort of will" that "is necessary in order to wrest, amidst the work and care of the daily round, scope and time for conceiving and working out the new combination and to bring oneself to look upon it as a real possibility and not merely as a day-dream. This mental freedom presupposes a great surplus force over the everyday demand and is something peculiar

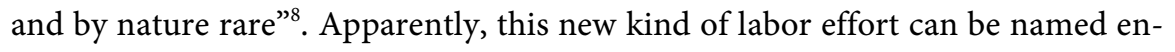
trepreneurial effort or entrepreneurial work.

Schumpeter particularly pointed out the entrepreneurial effort he mentioned was not limited to the effort made for business but for every aspect in the society.

${ }^{6}$ For those who are interested in this information, please see pp. 8-12 in Lowrey [10].

${ }^{7}$ Schumpeter [11], pp. 22-23.

${ }^{8}$ Schumpeter [11], pp. 86. 
"Unlike people running routings, the entrepreneur relies less than they do on tradition and connection and because his characteristic task-theoretically as well as historically-consists precisely in breaking up old, and creating new, tradition. Although this applies primarily to his economic action, it also extends to the moral, cultural, and social consequences of it".

At this point, Schumpeter realized the limitation of Gossen's Law in explaining the entrepreneur's behavior and recognized that it was "no mere coincidence that the period of the rise of the entrepreneur type also gave birth to Utilitarianism". Because of the entrepreneur's conduct and her motive were "rational" but not in the "sense of his characteristic motivation of the hedonist kind," he suggested, if "we define hedonist motive of action as the wish to satisfy one's wants, we may indeed make 'wants' include any impulse whatsoever, just as we may define egoism so as to include all altruistic values too, on the strength of the fact that they also mean something in the way of self-gratification".

\subsection{Production and Preference}

We assume that the economy is inhabited by a representative entrepreneur who conducts two types of productions that produce two types of goods respectively. One type of production produces subsistence goods, $y^{1}$ (say, making bread, or sewing cloth, or cleaning bathroom) and the other produces entrepreneurial goods, $y^{2}$ (say, inventing a new cell phone, or discovering a new energy source, or forming a nonprofit organization to foster entrepreneurship among the poor in the society). The representative entrepreneur consumes these two goods, subsistence goods and entrepreneurial goods, which are denoted by $c^{1}$ and $c^{2}$ respectively.

For the simplicity of the study, this model omits other factors in the production functions so that it can solely focus on the decision making of the entrepreneur in the economy. The input of those two productions is only labor effort: the labor effort $\ell$ for subsistence good production $y^{1}$, with the production function $f(\ell)$,

$$
y^{1}=f(\ell)
$$

and the entrepreneurial work $e$ for entrepreneurial production $y^{2}$, with the production function $\varphi(e)^{10}$,

${ }^{9}$ Schumpeter [11], p. 92.

${ }^{10}$ The idea can be also supported by Baumol [12]. In this paper, Baumol proposed that "it is necessary for us to differentiate between the entrepreneurial and the managerial functions". He suggested that "we may define the manager to be the individual who oversees the ongoing efficiency of continuing processes. It is his task to see that available processes and techniques are combined in proportions appropriate for current output levels and for the future outputs that are already in prospect. $\mathrm{He}$ sees to it that inputs are not wasted, that schedules and contracts are met, he makes routine pricing and advertising outlay decisions, etc., etc. in sum, he takes charge of the activities and decisions encompassed in our traditional models"...."The entrepreneur (whether or not he in fact also doubles as a manager) has a different function. It is his job to locate new ideas and to put them into effect. He must lead, perhaps even inspire; he cannot allow things to get into a rut and for him today's practice is never good enough for tomorrow". 


$$
y^{2}=\varphi(e)
$$

The total time endowment of the entrepreneur is 1 , so we have,

$$
\ell+e=1
$$

Production functions $f(\ell)$ and $\varphi(e)$ are both defined only for nonnegative values of the input and output levels $f(\ell)>0$ (the entrepreneur has at least to eat food and wear clothes), and $\varphi(e) \geq 0$; and both production functions are defined as an increasing function of inputs ${ }^{11}$, i.e., $f_{\ell}=\frac{\mathrm{d} f(\ell)}{\mathrm{d} \ell}>0$, $\varphi_{e}=\frac{\mathrm{d} \varphi(e)}{\mathrm{d} e}>0$.

In defining the entrepreneur as an economic agent who is ingenious and creative in finding ways to add to their own wealth, power, and prestige, Baumol [13] suggests that individuals choose to be entrepreneurs when or because their utility (from wealth, power, prestige or self-satisfaction) is maximized by so doing. Therefore, it is assumed that the utility function of the entrepreneur is $U\left(c^{1}, c^{2}, e\right)$. We adopt a simplified form of $U(\cdot)$ as the following ${ }^{12}$ :

$$
U\left(c^{1}, c^{2}, e\right)=u^{1}\left(c^{1}\right)+u^{2}\left(c^{2}\right)+u^{3}(e)
$$

where each component $u^{i}(i=1,2$, and 3$)$ is a nonnegative and increasing function of its corresponding argument, $c^{1}, c^{2}$ and $e$.

It is important to further elaborate $u^{3}(e)$, the utility function of entrepreneurial work. There has been heated discussion amongst scholars in religion and philosophy, Locke [14] and Weber [15] [16], for example, on the evolution of human's attitude toward work. Weber clearly attributed the great economic prosperity and social progress to the "protestant ethic", and observed that contributing to the prosperity "is a source of pleasure and pride to the modern entrepreneur and helps to give him an 'enjoyment of life"'13. We incorporate these ideas into a mathematical language below,

$$
\frac{\mathrm{d} u^{3}(e)}{\mathrm{d} e}=u_{e}>0
$$

That is, the entrepreneur is not an ascetic person. Rather, she works very hard because she enjoys what she is doing and takes pleasure in so doing. A good example of this positive utility function from working is the contentment gained by a health-conscious person who works in a gym. The harder she works the higher fulfillment she acquires. Because of the limit of human physical and mental capacity, the marginal utility of entrepreneurial work is assumed to be decreasing. That is, we assume $\mathrm{d}^{2}\left[u^{3}(e)\right] / \mathrm{d} e^{2}=u_{e e}<0$.

The entrepreneur's supply of $y^{2}$ creates its own demand, $c^{2}$, in accordance with Say's law of market, the place determines the price, $P$ (it is the relative price of $y^{2}$ in terms of the price of $y^{1}$, which is normalized to be 1$)$.

${ }^{11}$ See "The Theory of the Firm" in James Henderson and Richard Quandt (1971), Microeconomic Theory: A Mathematical Approach, Second Edition, McGraw-Hill Book Company.

${ }^{12}$ See Eugene Silberberg [13] for excellent mathematical reference.

${ }^{13}$ Weber [16], p. 26. 


$$
\begin{aligned}
& c^{1} \leq y^{1} \\
& c^{2} \leq y^{2}
\end{aligned}
$$

For the chosen allocation of labor effort $(1-e)$ and entrepreneurial effort $e$ for respectively producing $y^{1}$ and $y^{2}$, and the chosen consumption bundle $c^{1}$ and $c^{2}$, the entrepreneur's utility function is at the maximum level.

Hence, the entrepreneur's optimization problem will be:

$$
\begin{aligned}
& \max _{c^{1}, c^{2}, e} U\left(c^{1}, c^{2}, e\right)=u^{1}\left(c^{1}\right)+u^{2}\left(c^{2}\right)+u^{3}(e) \\
& \text { s.t. } \quad c^{1}+P c^{2} \leq y^{1}+P y^{2}=f(1-e)+P \varphi(e)
\end{aligned}
$$

\subsection{Analysis and Discussions of the Equilibrium}

We will analyze and discuss the equilibrium of aforementioned entrepreneurial economy in this section. Following the previous model setup, we have the following proposition:

Proposition 1: In equilibrium, the relative price of entrepreneurial goods to subsistence goods is lower than the ratio of the marginal product of labor in subsistence production to that in entrepreneurial production.

Proof: The Lagrangian for the optimization problem (3) is,

$$
\mathcal{L}\left(c^{1}, c^{2}, e, \lambda\right)=u^{1}\left(c^{1}\right)+u^{2}\left(c^{2}\right)+u^{3}(e)+\lambda\left[f(1-e)+P \varphi(e)-c^{1}-P c^{2}\right]
$$

Here $\lambda$ is Lagrangian multiplier on the resource constraint. Differentiating $\mathcal{L}$ with respect to each of the arguments, $c^{1}, c^{2}, e$ and $\lambda$, to obtain the following four first order conditions

$$
\begin{gathered}
\frac{\partial \mathcal{L}}{\partial c^{1}}=u_{1}-\lambda=0 \\
\frac{\partial \mathcal{L}}{\partial c^{2}}=u_{2}-\lambda P=0 \\
\frac{\partial \mathcal{L}}{\partial e}=u_{e}-\lambda\left(f_{\ell}-P \varphi_{e}\right)=0 \\
\frac{\partial \mathcal{L}}{\partial \lambda}=f(1-e)+P \varphi(e)-c^{1}-P c^{2}=0
\end{gathered}
$$

where $u_{1}=\frac{\mathrm{d} u^{1}}{\mathrm{~d} c^{1}}, u_{2}=\frac{\mathrm{d} u^{2}}{\mathrm{~d} c^{2}}, u_{e}=\frac{\mathrm{d} u^{3}}{\mathrm{~d} e}$.

From these first order conditions, we derive market equilibrium price results below

$$
\begin{gathered}
\frac{u_{2}}{u_{1}}=P^{*} \\
\frac{u_{e}}{u_{1}}=f_{\ell}-P^{*} \varphi_{e}
\end{gathered}
$$

We know $u_{e}>0$ and $u_{1}>0$. This means,

$$
\frac{u_{e}}{u_{1}}=f_{\ell}-P^{*} \varphi_{e}>0
$$


Because $\varphi_{e}>0$, the market relative price of entrepreneurial good in terms of subsistence good $P^{*}$ is determined as below

$$
P^{*}<\frac{f_{\ell}}{\varphi_{e}} \text { or } f_{\ell}>P^{*} \varphi_{e}
$$

Equation (5) illustrates the market equilibrium price, $P^{*}$, must equate the marginal rate of substitution between the two products, i.e. $u_{e} / u_{1}$. This result is consistent with the traditional neoclassical prediction. Equation (7) shows the market determined relative price $P^{*}$ must be less than the ratio of marginal productivity of subsistence good over entrepreneurial good; in other words, the market value of the marginal product of labor in subsistence production needs to be greater than that in entrepreneurial production. This result corrects deficiency of mainstream economics in overlooking entrepreneurial work ethic. Acknowledging entrepreneurs' work ethic, a market system would create higher pressure on subsistence production to be more efficient in an entrepreneurial economy's maximization problem. Due to the enjoyment of entrepreneurial work itself, the representative agent would like to accept a relative low compensation to work in the entrepreneurial sector.

We see this result as a good explanation of wide spread-out outsourcing in developed countries. Following Maslow's hierarchy theory of needs ${ }^{14}$, we can reasonably assume that high-income nations tend to have a higher percentage of citizens take part in entrepreneurial activities.

\section{Government Intervention}

In this section, we investigate the effects of government intervention in an entrepreneurial economy. Oftentimes, a government would encourage society to produce an adequate amount of subsistence goods, by subsidizing the production of subsistence goods (such as food, housing, and utility supplies).

To this end, we assume that the government imposes a lump sum tax $\tau$ to finance its expenditure $G$ that is all spent on a price subsidy for subsistence production at the rate of $\delta$. The government has to balance its budget, i.e. $G=\tau$.

Hence, the entrepreneur's optimization problem becomes

$$
\begin{gathered}
\max _{c^{1}, c^{2}, e} U\left(c^{1}, c^{2}, e\right)=u^{1}\left(c^{1}\right)+u^{2}\left(c^{2}\right)+u^{3}(e) \\
\text { s.t. } \quad c^{1}+P c^{2}+\tau \leq y^{1}+P y^{2}=(1+\delta) f(1-e)+P \varphi(e) \\
\tau=\delta f(1-e)
\end{gathered}
$$

Proposition 2: When the government attempts to subsidize the subsistence production, it distorts the market equilibrium price allocating the entrepreneur's time into subsistence vs. entrepreneurial production. A higher rate of subsidy on subsistence production will reduce the time allocated to entrepreneurial work.

Proof: Together with (3), the Lagrangian of this new optimization problem becomes,

${ }^{14}$ Maslow [5] 


$$
\begin{aligned}
& \mathcal{L}\left(c^{1}, c^{2}, e, \lambda\right) \\
& =u^{1}\left(c^{1}\right)+u^{2}\left(c^{2}\right)+u^{3}(e)+\lambda\left[(1+\delta) f(1-e)+P \varphi(e)-\tau-c^{1}-P c^{2}\right]
\end{aligned}
$$

Here $\lambda$ is Lagrangian multiplier on the resource constraint. Differentiating $\mathcal{L}$ with respect to each of the arguments, $c^{1}, c^{2}, e$ and $\lambda$ to obtain the following four first order conditions:

$$
\begin{gathered}
\frac{\partial \mathcal{L}}{\partial c^{1}}=u_{1}-\lambda=0 \\
\frac{\partial \mathcal{L}}{\partial c^{2}}=u_{2}-\lambda P=0 \\
\frac{\partial \mathcal{L}}{\partial e}=u_{e}-\lambda\left((1+\delta) f_{\ell}-P \varphi_{e}\right)=0 \\
\frac{\partial \mathcal{L}}{\partial \lambda}=(1+\delta) f(1-e)+P \varphi(e)-\tau-c^{1}-P c^{2}=0
\end{gathered}
$$

where $u_{1}=\frac{\mathrm{d} u^{1}}{\mathrm{~d} c^{1}}, u_{2}=\frac{\mathrm{d} u^{2}}{\mathrm{~d} c^{2}}, u_{e}=\frac{\mathrm{d} u^{3}}{\mathrm{~d} e}$.

From these first order conditions, obtain

$$
\begin{gathered}
\frac{u_{2}}{u_{1}}=P^{*}>0 \\
\frac{u_{e}}{u_{1}}=(1+\delta) f_{\ell}-P^{*} \varphi_{e}>0
\end{gathered}
$$

Given $u_{e}>0$ and $u_{1}>0$, we also assume all utility functions and productions are well-behaved concave, i.e. the first order conditions of these functions to be positive and the second order conditions to be negative.

$$
\frac{u_{e}}{u_{1}}-\delta f_{\ell}=f_{\ell}-P^{*} \varphi_{e}
$$

Totally differentiate the Equation (10) with respect to entrepreneurial work $e$ and government policy subsidizing subsistence production, $\delta$, obtain

$$
\begin{gathered}
\frac{u_{e e}}{u_{1}} \mathrm{~d} e+\delta f_{\ell \ell} \mathrm{d} e-f_{\ell} \mathrm{d} \delta=-f_{\ell \ell} \mathrm{d} e-P^{*} \varphi_{e e} \mathrm{~d} e \\
{\left[f_{\ell \ell}+P^{*} \varphi_{e e}+\frac{u_{e e}}{u_{1}}+\delta f_{\ell \ell}\right] \mathrm{d} e=f_{\ell} \mathrm{d} \delta} \\
\frac{\mathrm{d} e}{\mathrm{~d} \delta}=\frac{f_{\ell}}{\left[f_{\ell \ell}+P^{*} \varphi_{e e}+\frac{u_{e e}}{u_{1}}+\delta f_{\ell \ell}\right]}
\end{gathered}
$$

Based on assumptions, we know $f_{\ell \ell}<0, \varphi_{e e}<0, u_{e e}<0, f_{\ell \ell}<0$, and $f_{\ell}>0, u_{1}>0, P^{*}>0$.

So we finally have,

$$
\frac{\mathrm{d} e}{\mathrm{~d} \delta}<0
$$

From Equation (10) we find $P^{*}<(1+\delta) f_{\ell} / \varphi_{e}$. Comparing to Equation (7), 
this result implies that the government's subsidy on subsistence production would in fact insert an inefficient "wedge" between subsistence production and entrepreneurial production. As stated in Proposition 2, Equation (12) shows that a higher rate of subsidy on subsistence production would lower the level of entrepreneurial effort to achieve the market equilibrium. In other words, government's subsidization of the subsistence sector has a negative impact on entrepreneurial work.

\section{Conclusions}

This research is inspired by Baumol's lifetime effort in introducing the entrepreneur to mainstream economics. We have found classical labor theory and discussions on work ethic to be the best way to fill the gap between entrepreneurs in economics and in the real world. We follow the research tradition of Max Weber and Joseph Schumpeter on entrepreneurship and claim that the entrepreneurial work is the intrinsic character of the entrepreneur who proactively utilizes her essential human capital-her labor owned by herself-for producing both subsistence and entrepreneurial goods and services. The idea of categorizing two types of entrepreneurs' work was originated by Schumpeter. $\mathrm{He}$ often divided entrepreneurs into managers vs. innovators. Baumol also distinguished between innovative vs. replicative entrepreneurs ${ }^{15}$. In this paper, we incorporate these ideas into our analytical model.

The contribution of our paper to the economics of entrepreneurship is to classify two types of work that result in different utilities. The entrepreneur's working time in subsistence production is assumed to generate disutility, the same assumption as that of mainstream economics; yet the time devoted to entrepreneurial production is assumed to derive satisfaction. Under these assumptions, the utility maximization produces a higher market value of marginal subsistence production than that of entrepreneurial production. However, misallocation of labor effort could occur due to government interventions artificially changing the price of subsistent production.

This paper has a great potential for further explorations on entrepreneurship. For example, adding a risk factor into the model and measuring entrepreneurial work by differentiating individual's abilities or experiences can provide a better understanding of the nature of entrepreneurs in an economy. Also, we need micro-level data to empirically test our theory of entrepreneurial work. Finally, we would like to use the model to analyze the attributes and institutional settings of "Entrepreneurship" in Baumol [13], which proposes that entrepreneurship can be productive, unproductive, or destructive.

\section{Acknowledgements}

Ying Lowrey is very much indebted to the late Professor William Baumol for his guidance and collaboration between 2001 and 2017. She is also grateful for the

\footnotetext{
${ }^{15}$ The particular example was Baumol [17].
} 
support and encouragement from the Ewing Marion Kauffman Foundation and the Office of Advocacy, US Small Business Administration during her writing on the earlier version of this paper. Any errors in this paper are our own.

\section{Conflicts of Interest}

The authors declare no conflicts of interest regarding the publication of this paper.

\section{References}

[1] Baumol, W.J. (2002) Free-Market Innovation Machine: Analyzing the Growth Miracle of Capitalism. Princeton University Press, Princeton. https://doi.org/10.1515/9781400851638

[2] Filion, L.J. (1997) From Entrepreneurship to Entreprenology. 42nd World Conference, San Francisco, 21-24 June 1997, 176-192.

[3] Calvin, K.A., Sexton, D.L. and Vesper, K.H. (1982) Encyclopedia of Entrepreneurship. Prentice-Hall, Inc., Upper Saddle River.

[4] McClelland, D.C. (1971) The Achievement Motive in Economic Growth. In: Kilby, P., Ed., Entrepreneurship and Economic Development, The Free Press, New York, 108-122.

[5] Maslow, A.H. (1943) A Theory of Human Motivation. http://citeseerx.ist.psu.edu/viewdoc/download?doi=10.1.1.318.2317\&rep=rep1\&type $=\mathrm{pdf}$ https://doi.org/10.1037/h0054346

[6] Maslow, A.H. (1954) Motivation and Personality. Harper \& Row, Publishers, Inc., New York.

[7] Schumpeter, J.A. (1942) Capitalism, Socialism and Democracy. Harper \& Brothers, New York.

[8] Schumpeter, J.A. (1951) Essays on Entrepreneurs, Innovations, Business Cycles, and the Evolution of Capitalism.

[9] Clark, K. and Tomlinson, M. (2001) The Determinants of Work Effort: Evidence from the Employment in Britain Survey. University of Manchester School of Economics Discussion Paper, Manchester.

[10] Lowrey, Y. (2006) An Examination of the Entrepreneurial Effort. Presented at the 2006 American Economic Association Annual Meetings, 7 January, 2006 in Boston. https://ssrn.com/abstract $=889068$

[11] Schumpeter, J.A. (1934) Theory of Economic Development.

[12] Baumol, W.J. (1968) Entrepreneurship in Economic Theory. American Economic Review, 58, 64-71.

[13] Baumol, W.J. (1990) Entrepreneurship: Productive, Unproductive, and Destructive. Journal of Political Economy, 98, 893-921. https://doi.org/10.1086/261712

[14] Locke, J. (2002) Second Treatise on Government and a Letter Concerning Toleration. Dover Publications, Inc., New York.

[15] Weber, M. (1978) Selections in Translation. Cambridge University Press, Cambridge. https://doi.org/10.1017/CBO9780511810831

[16] Weber, M. (2002) The Protestant Ethic and the "Spirit" of Capitalism and Other 
Writings. Penguin Classics, London.

[17] Baumol, W.J. (2010) The Microtheory of Innovative Entrepreneurship. Princeton University Press, Princeton. https://doi.org/10.1515/9781400835225 